\begin{tabular}{cl}
\hline 2020, T. 162, KH. 1 & ISSN 2541-7738 (Print) \\
C. $177-190$ & ISSN 2500-2171 (Online)
\end{tabular}

УДК 94(3)+94(4)

doi: 10.26907/2541-7738.2020.1.177-190

\author{
АНТИКИЗИРОВАННЫЕ ЭМБЛЕМЫ АЛЬЦИАТА* \\ Е.С. Данилов \\ Ярославский государственный университет им. П.Г. Демидова, \\ г. Ярославль, 150003, Россия
}

\begin{abstract}
Аннотация
В статье анализируется содержание «Книги эмблем» позднеренессансного писателя Альциата Медиоланского (1492-1550). Обращается внимание на отдельные группы мифологических персонажей и исторических личностей классической древности. Автор статьи отмечает превалирующее обращение Альциата именно к мифологическим существам. Выявляются основные произведения греческих и римских авторов, ставших источниками для Андреа Альчиато. В частности, немаловажным источником вдохновения для Альчиато явилась «Палатинская антология», басни Эзопа и Авиана. В статье проанализировано 155 символических композиций (73\% от общего числа). По мнению автора, они указывают на безусловную связь эмблематической интенции Андреа Альчиато с литературным наследием классической древности. Книга итальянского гуманиста изначально предназначалась для эрудированной публики. Теоретическая мысль последующих эмблематистов также не в малой степени питалась от греко-римских истоков. Но первым на данном жанровом поприще был именно Альциат.
\end{abstract}

Ключевые слова: эмблема, Альчиато, античная культура

В апреле 2015 г. состоялась первая в России конференция по эмблематике. Круглый стол «Эмблематика в европейской культуре» организовали гуманитарный клуб «Intrada» совместно с Институтом филологии и истории Российского государственного гуманитарного университета и Институтом мировой литературы РАН. В 2016 г. на основе представленных на данном мероприятии докладов была выпущена коллективная монография, уникальная в своем роде [1]. Безусловно, можно говорить о превращении отечественного эмблематоведения в отдельное научное направление. В этом отношении представляется актуальным обращение к истокам эмблематического дискурса.

Миланский юрист первой половины XVI в. Джованни Андреа Альчиато ${ }^{1}$ (рис. 1) является автором нескольких трактатов, самый известный из которых носит название “Emblematum liber” («Книга эмблем»)". Данный труд, впервые

\footnotetext{
* В основе настоящей статьи лежит доклад, представленный 5 февраля 2016 г. на Всероссийской научной конференции с международным участием «Феноменология античного духа: Актуальные проблемы классической литературы, философии, мифологии, религии и искусства» (III Авторско-читательская конференция альманаха «Antiquitas Aeterna», Нижегородский государственный университет им. Н.И. Лобачевского).

${ }^{1}$ Различные варианты написания фамилии Альчиато (Альчиати, Альциат) являются взаимозаменяемыми и общепризнанными.

2 Об Альчиато и его работах см. [2; 3, p. 254-260; 4-6].
} 


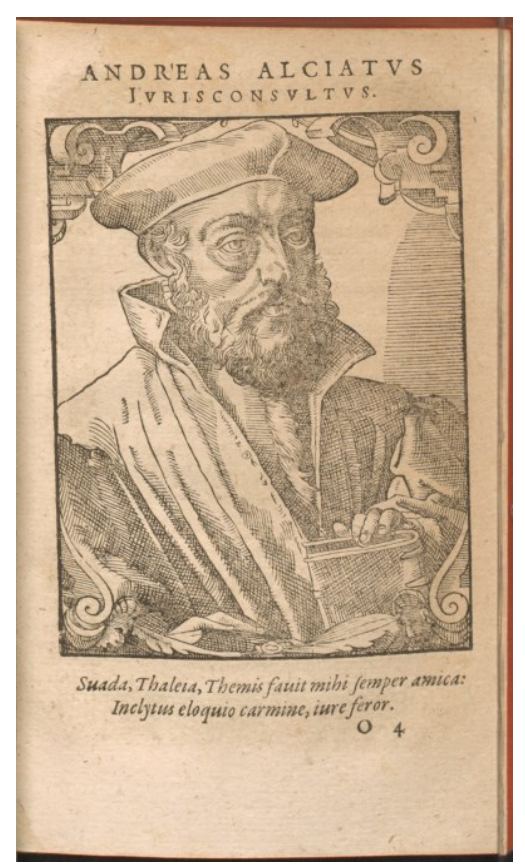

Рис. 1. Андреа Альчиато. Книжная гравюра 1589 г. Источник - веб-сайт библиотеки Корнелльского университета. URL: https://digital.library.cornell.edu/catalog/ss:574286, свободный

изданный в Аугсбурге в 1531 г., содержит аллегорические изображения с поясняющими надписями на латинском языке (Alciati 1531). Одно из самых полных, падуанское издание 1621 г. включает 212 эмблем ${ }^{3}$, представляющих различные моральные ценности, пороки и политические категории (Alciati 1621). Рассмотрим подробнее те страницы, где, как нам кажется, проявилось влияние античной культуры.

Предварительно следует отметить, что Альциат получил хорошее образование и уже в юном возрасте, в 1508 г., подготовил подборку античных эпиграфических памятников, обнаруженных в Миланском герцогстве. Позднее он написал историю Медиолана, доведя изложение до правления Валентиниана I (издана лишь в 1625). Высоко ценились его заметки к трудам Тацита (1517), работа «О значении слов» и «Книга о весах и мерах» (обе напечатаны в 1530), в которых реконструировались реалии средиземноморских цивилизаций. Первые юридические труды Альчиато представляли собой комментарии к Дигестам и Кодексу Юстиниана (1515) [10; 11, p. 16-37]. Иными словами, Альчиато можно считать не только правоведом, но также историком, филологом и антикварием. Итальянский математик и врач Джироламо Кардано (1501-1576), лично знакомый с Альчиато, характеризовал его также как превосходного оратора (Cardano 2012, c. 71, 72, 209).

\footnotetext{
${ }^{3}$ Для Альчиато «эмблемой» была сама эпиграмма, то есть нечто словесное. Эмблема, которая сложилась в эпоху барокко, в обязательном порядке являет собой сочетание трех компонентов: inscriptio - краткая надпись, заголовок; subscriptio - развернутая подпись, стихотворный текст; pictura - располагавшееся между

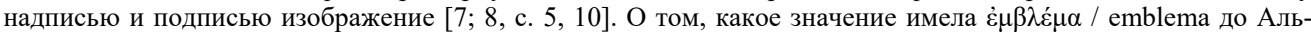
чиато см. [9].
} 
Возвращаясь к избранным нами символам, попытаемся их сгруппировать и охарактеризовать. Канонический порядок эмблем Альциата предусматривает тематическую организацию из 20 разделов с последующим более дробным членением. Например, самые объемные разделы "Virtutes" («Добродетели») и "Vitia" («Пороки») имеют по 6 и 7 частей соответственно, объединяя 88 эмблем (41.5\%). В основе нашей классификации антикизированных эмблем лежит деление по упоминающимся персонажам древней истории и мифологии, а также соответствующим сюжетам.

В первую очередь можно констатировать превалирующее обращение именно к мифологическим существам. Среди них по числу упоминаний лидируют обитатели Олимпа, но есть и достаточно редко встречающиеся божества, вроде Элпиды (№ XLIV), персонификации надежды, молчаливого Гарпократа (№ XI) или Аты (№ CXXXI), помрачающей человеческие умы (рис. 2). В рассмотренных эмблемах часто всплывают отсылки к подвигам Геракла ${ }^{4}$, деяниям аргонавтов (сыновья Борея, Пелей, Теламон, Язон) и активных участников Троянской войны (Ахилл, Аякс, Гектор, Одиссей). При объяснении отдельных аллегорий Альчиато использует образы монстров. Скажем, Минотавр представлен как символ военной тайны (№ XII), Сцилла увязывается с бесстыдством (№ LXVIII), Сфинкс с невежеством (№ CLXXXVIII), Медуза Горгона становится аллегорией скорбной судьбы (№ CLVII), а Химера - тирании (№ XIV).

Весьма любопытен список реальных исторических деятелей, о которых вспоминает автор. Первым оказывается Александр Великий. В аннотации к третьей эмблеме он произносит фразу, являющуюся девизом рода Альчиато: «Никогда ничего не откладывать» ${ }^{5}$. Из представителей эллинизма в книге фигурируют скульпторы Пракситель (№ XXV) и Лисипп (№ CXXII), сиракузский тиран Дионисий II (№ XCI), полководец Ганнибал Барка (№ XXVI) и селевкидский правитель Антиох I Сотер (№ CXXIV).

Период классики представлен в основном философами (Гераклит Эфесский - № XVI, CLII; Сократ - № LXI; Демокрит - № CLII), драматургами (Эпихарм - № XVI; Софокл - № CXVII) и поэтами (Пиндар, Вакхилид № CXL). К архаической эпохе относятся Гомер (№ CCI); «семь мудрецов» (№ CLXXXVII); сатирик Архилох (№ LI) и лирик Алкей (№ LXIII).

Из греческих государственных деятелей архаики и классики Альчиато выделяет Аристомена, Солона и Фрасибула. Могилу мессенского героя (Paus. IV. 32. 3) венчает орел как своеобразный знак храбрости почившего (№ XXXIII). Афинский законодатель вспоминается как мудрец, советующий каждому помнить о конце жизни ((№ CLXXXVII. 11-12); cp. (Hdt. I. 32; Plut. Sol. 28)), а также в связи с предписанием молодоженам употреблять в пищу кидонские яблоки (плоды айвы) для более сладостного дыхания ((№ CCIV); cp. (Plut. Mor. 138D)).

\footnotetext{
4 Эмблемы № LVIII, CXXXVIII, CXXXIX, CLXXXI, CCXII.

${ }^{5}$ Emblema III. Nunquam procrastinandum: "Alciatae gentis insignia sustinet Alce, / Unguibus et $\mu \eta \delta \dot{\varepsilon} v$ fert

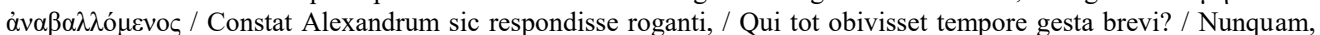
inquit, differre volens. Quod et indicat Alce: / Fortior haec, dubites, ocior anne siet”. Наш примерный перевод следующий: «Лось поддерживает знак (инсигнию) рода Альчиато (игра слов alces (лось) - Alciatus) / Копытами «Никогда не откладывай». / Таким образом ответил Александр, когда его спросили / "Как он совершил так много подвигов за короткое время?” / “Не желая, - сказал он, - отложить”. На это также указывает лось. / Вы можете спросить, сильнее ли он или быстрее». Самый вероятный источник этой сентенции македонского царя - Схолии к «Илиаде» (II. 435). См. (Alciati 1621, p. 24).
} 


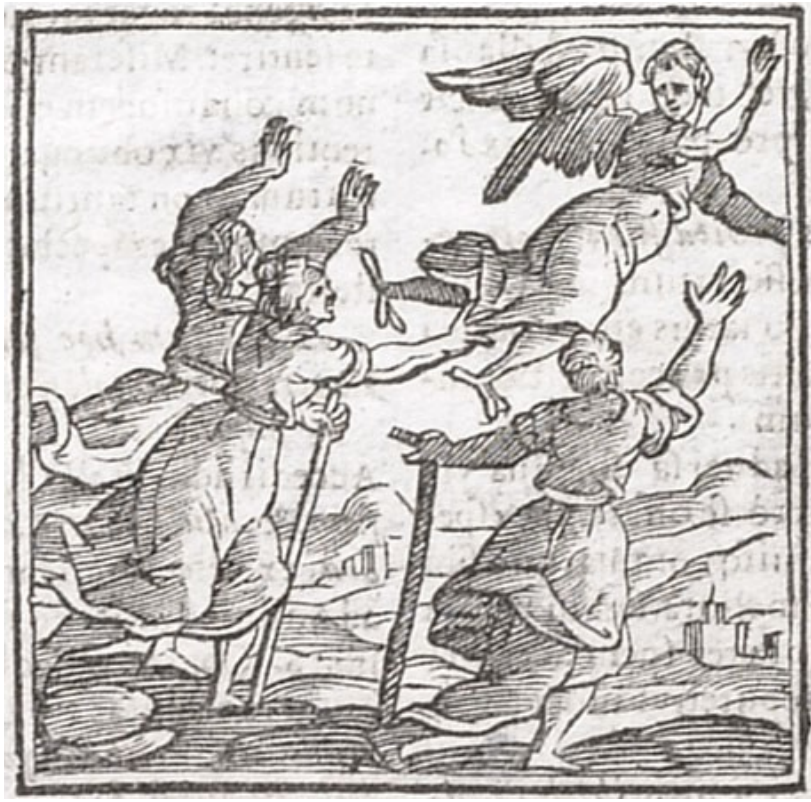

Рис. 2. Хромые Литы, богини просьб, медленно следуют за быстрокрылой Атой, богиней обмана и глупости, исправляя причиненные ею бедствия. Emblema CXXXI. Remedia in arduo, mala in prono esse (Лекарство в трудности, беды в легкости). Здесь и далее источник пиктур издания эмблем Альчиато 1621 г. - веб-сайт библиотеки Университета Глазго. URL: https://www.emblems.arts.gla.ac.uk/alciato/contents.php?id=A21a, свободный

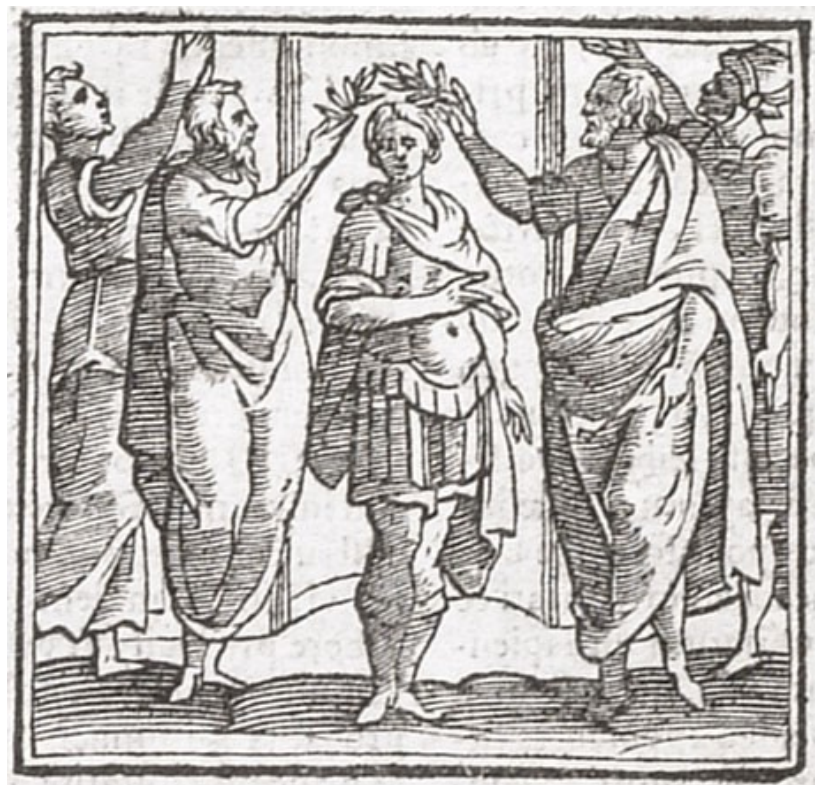

Рис. 3. Награждение Фрасибула лавровым венком. Emblema CXXXV. Optimus civis (Лучший гражданин)

Полководец Фрасибул награждается лавровым венком за успешную борьбу против тирании Тридцати (Nep. Thrasyb. 4) и провозглашается лучшим гражданином (№ CXXXV) (рис. 3). Единственный грек времен Римской империи, отмеченный 
в опусе Альчиато, - это стоик Эпиктет. «Выдержи и воздержись» (“Sustine et abstine"), - повторяет вслед за ним средневековый эллинофил, а неизвестный художник иллюстрирует высказывание изображением быка, удаляемого от ко-

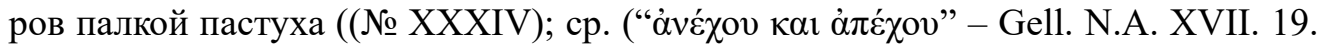
6)).

В этой связи необходимо оговориться, что визуальное воплощение словесных эмблем Альциата появилось лишь благодаря издателям. В 1531 г. это был печатник Генрих Штайнер, а в нашем случае - книготорговец Пьетро Паоло Тоцци, использовавший в Падуе типографию Лоренцо Паскуато. Причем иллюстраторы, по словам искусствоведа Эрвина Панофского, со временем демонстрируют всё большее пренебрежение теми смыслами, которые вкладывал в эмблемы Альчиато [12, с. 190-191].

Обратимся к гравюрам с римской тематикой. Оригинальной можно считать эмблему XXVI “Gramen” («Трава»). Во-первых, она содержательно состоит из трех частей. Далее, во всех этих частях по-разному указывается на силу растений, но на пиктуре запечатлена только одна сцена: консул Квинт Фабий Максим Кунктатор увенчивается венком из трав за победу над карфагенским полководцем Ганнибалом (Plin. N.H. XXII. 4. 6; Gell. N.A. V. 6. 10). Альчиато добавляет строки о жаровонке, прячущем гнездо в высоких зарослях, и рыбаке Главке, который стал морским богом из-за съеденной муравы (Ath. VII. 296e, XV. 679a; Ovid. Met. XIII. 916-965). Таким образом подчеркивается почетно-символическое, ритуальное значение растений, а также подразумевается контекст безопасности.

Марк Антоний предстает перед нами в апогее гордыни. Как сообщает Плиний Старший, сторонник Цезаря первым в Риме проехался на колеснице, запряженной львами (Plin. N.H. VIII. 21. 55; cp. Plut. Ant. 9). Альчиато обвиняет его в смерти Цицерона и называет проклятием своей страны (№ XXIX) (рис. 4).

Два эпизода из жизни Марка Юния Брута показаны в эмблемах № CXX и CLI. В первом случае демонстрируется сцена самоубийства Брута, который упрекает Фортуну, одержавшую верх над его доблестью (Plut. Brut. 52). Правда, при этом почему-то упоминается Фарсальское сражение, а не битва при Филиппах. Во втором случае мы видим символы свободы: кинжалы и фригийский колпак (рис. 5), отсылающие нас к известной монетной чеканке республиканцев и указывающие на знакомство Альчиато с античной нумизматикой ${ }^{6}$.

О гражданских войнах в Риме, без привязки к какому-либо периоду, говорится также в субскрипции № XXXIX и посредством изображения военныХ значков в пиктуре № CCVI.

Надпись, сопровождающая эмблему под номером XXXII, пропитана едкой сатирой. В ней повествуется о двух богатых землевладельцах, Марии и Суббарде ${ }^{7}$, которые возводят столь высокие стены, что их бедный сосед лишается естественного освещения. Богачи сравниваются с хищными гарпиями, а честный и добродетельный бедняк со страдальцем Финеем (Ps.-Appolod. Bibl. I.9.21).

\footnotetext{
${ }^{6}$ Emblema CLI. Respublica liberata: "Caesaris exitio, ceu libertate recepta, / Haec ducibus Brutis cusa moneta fuit. / Ensiculi in primis, queis pileus insuper astat, / Qualem missa manu servitia accipiunt” ( «После смерти Цезаря, когда свобода была восстановлена, / Эта монета была отчеканена для военачальников Брута. / В первую очередь кинжалы, над ними - шапка, / Которую рабы получают при освобождении») (Перевод наш. - E.Д.). Подробнее об эмблематической интерпретации данной монетной чеканки см. [13].

7 "Subbardus", sub bardus - придурок?
} 


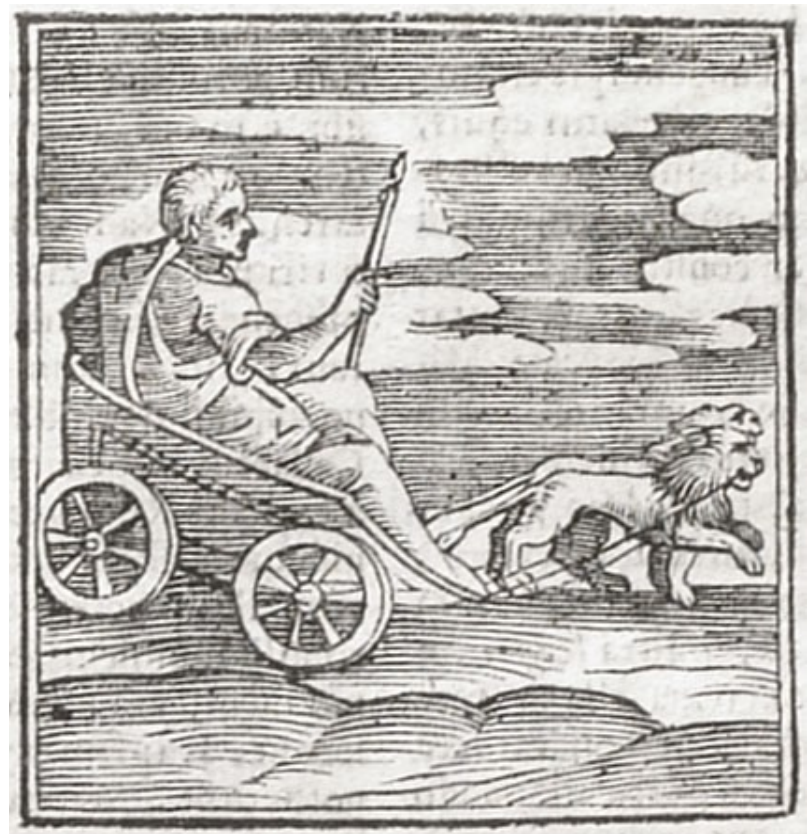

Рис. 4. Марк Антоний. Emblema XXIX. Etiam ferocissimos domari (И самые яростные приручаются)

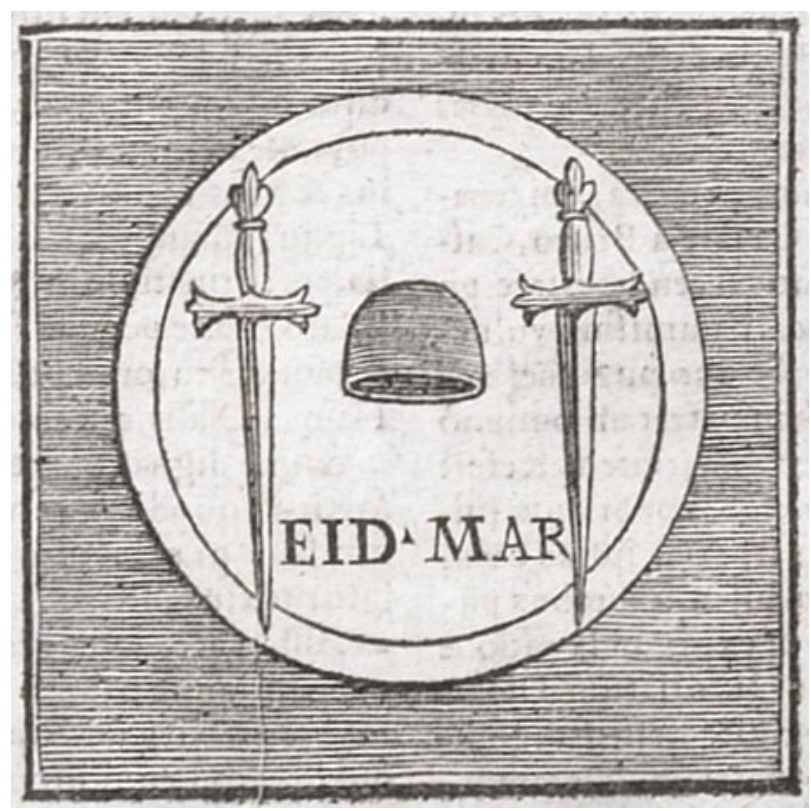

Рис. 5. Монета Марка Юния Брута. Emblema CLI. Respublica liberata (Освобожденное государство)

Знаменитый римский гурман Марк Габий Апиций (Mart. Epigr. III. 22) становится персонажем эмблемы № XСI. Мужчина с длинной шеей и раздутым животом держит чайку и пеликана. Выбирая, что приготовить, он похож, по мнению Альциата, на Дионисия Младшего (Ath. X. 435d-e), Апиция и всех чревоугодников. 
Изображение больного с увеличенной селезенкой (№ CXLVII) должно напомнить читателям высказывание императора Траяна, сравнившего государственную казну с внутренним органом. Если казна набухает, это свидетельствует об обеднении граждан (Aur. Vict. Epit. XLII. 21).

«Варвары» в книге Альциата занимают незначительное место. В связи с основанием кельтского поселения на месте будущего Медиолана упоминаются битуриги и эдуи (№II). Живущий у берегов Черного моря бедный гунн одевается в шкуры, не знает даров Лиэя (Вакха) и Цереры. Однако он может жить в безопасности, так как ему нечего терять (№ XXXVII) (рис. 6). Наконец, полчища Ксеркса и Аттилы уподобляются саранче (№ CXXVIII).

Еще меньше, чем о варварах, Альчиато пишет только о женщинах. Если не считать персонажей мифов, среди которых наибольшего внимания удостоилась Венера (11 эмблем), то у нас остаются только гетеры Леэна (№ XIII), Лайда (№ LXXIV) и Архиппа (№ CXVII). Возлюбленная Гармодия аллегорически показана в виде львицы без языка, охраняющая крепость Кекропа (Plin. N.H. XXXIV. 72; Plut. Mor. 505e; Paus. I. 23. 1-2; Polyaenus. Strat. VIII. 45). На саркофаге коринфской жрицы любви львица хватает барана. Альчиато интерпретирует барельеф, описанный еще Павсанием (Paus. II. 2. 4), как указание на жадность Лайды, крепко держащей своих любовников. Старец, обнимающий Архиппу, это - Софокл (рис. 7). Прежний поклонник девушки сравнил ее с совой, сидящей на трупе (Ath. XIII. 592b).

Немаловажным источником вдохновения для Альчиато явилась «Палатинская антология» ${ }^{8}$. Об ее использовании можно с осторожностью говорить в 43 случаях (20\%). 19 эмблем, вероятно, имеют свою первооснову в IX книге собрания византийского грамматика Константина Кефала. 10 эмблем относятся к XVI дополнительной книге Максима Плануда. Остальные стихотворения, отобранные Альчиато из антологии, - это эпитафии; застольные, посвятительные, нравоучительные и любовные эпиграммы. Для того чтобы лучше понять механизм литературной переработки античных творений, приглядимся к эмблеме XLII (рис. 8). Ее маловыразительная пиктура снабжена примечательной субскрипцией, которая содержательно базируется на описательной эпиграмме «Палатинской антологии» (Pal. Ant. IX. 291. Р. 157). Приведем ее текст в переводе Л.В. Блуменау: «Если бы хлынули даже все воды морского прилива, / Или Германия весь свой устремила бы Рейн, / Не ослабеет нисколько могущество Рима, покуда / Кесарь в деснице своей будет удерживать власть. / Так посвященные Зевсу дубы, укрепившись корнями, / Твердо стоят, а сухой ветром срывается лист» (Epigrammata Graeca 1993, с. 227, № 27). Поэт Кринагор Митиленский прославлял этими словами Октавиана Августа. Альциат, оставив метафору с дубом, поменял Рейн на Дунай, германцев на турок, вышеозначенного принцепса на Карла V Габсбурга 9 .

\footnotetext{
${ }^{8}$ За два года до выхода первой “Emblematum liber” в Базеле было напечатано собрание "Selecta epigrammata graeca” («Избранные греческие эпиграммы») Яна Корнария, где рядом с каждой греческой эпиграммой приводился латинский перевод, выполненный выдающимися гуманистами, среди которых имена Лоренцо Валлы, Томаса Мора, Эразма Роттердамского и др. Вклад Альчиато в эту книгу составил не менее 140 переводов [14, с. 35].

9 "Oceanus quamvis fluctus pater excitet omnes; / Danubiumque omnem, barbare Turca, bibas: / Non tamen irrumpes perfracto limite, Caesar / Dum Carolus populis bellica signa dabit. / Sic sacrae quercus firmis radicibus adstant, / Sicca licet venti concutiant folia" (Emblema XLII. Firmissima convelli non posse).
} 


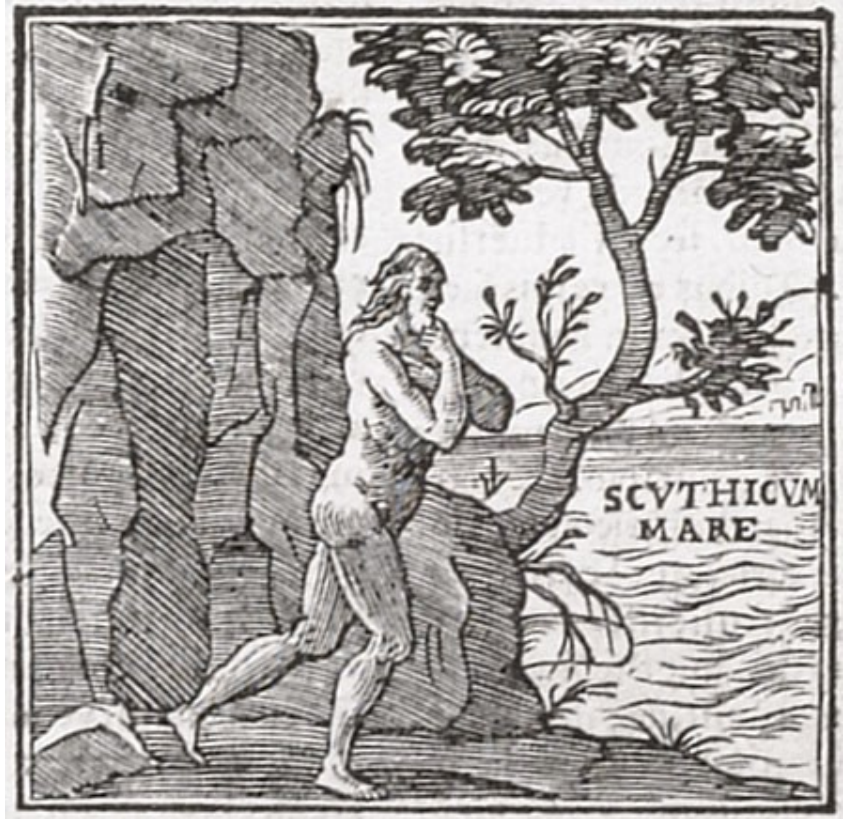

Рис. 6. Гунн у Чёрного моря. Emblema XXXVII. Omnia mea mecum porto (Bcё свое ношу с собой)

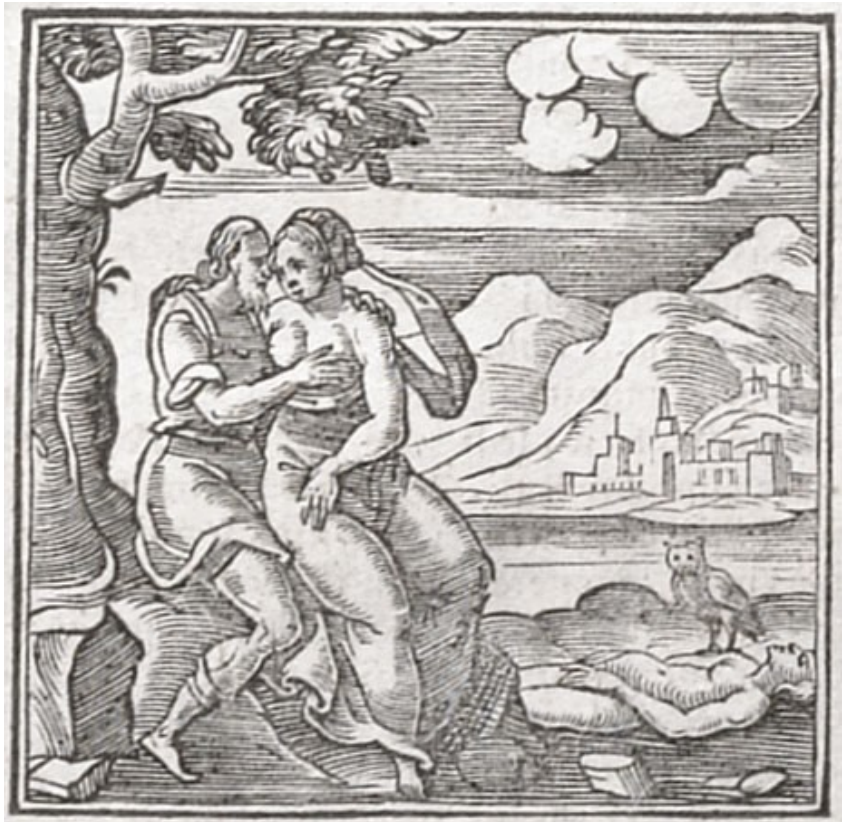

Рис. 7. Софокл и Архиппа. Emblema CXVII. Senex puellam amans (Старик влюбленный в деву) 


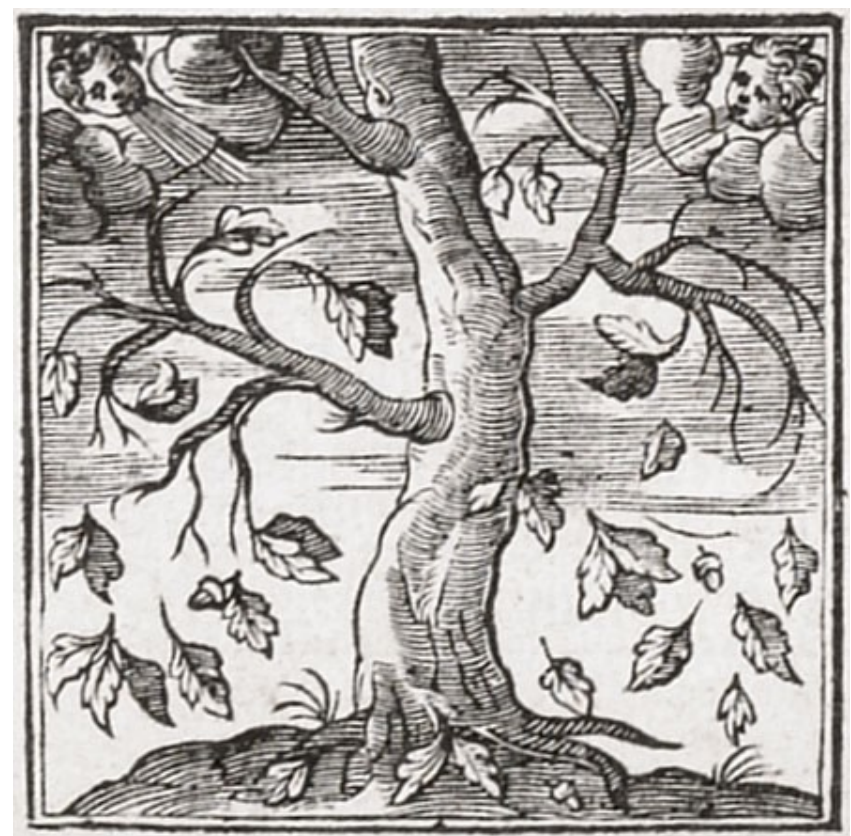

Рис. 8. Дуб - символ власти. Emblema XLII. Firmissima convelli non posse (Самое крепкое не может быть вырвано)

Отдельно стоит сказать об эмблемах, созданных по мотивам произведений Эзопа, хотя имя самого автора не называется (№ VII, L, CV, CXXVI, CLIII, CLXVI, CLXIX, CLXXIV, CLXXV, CLXXXIX, CXCIII). Остановимся на трех примерах из одиннадцати.

Присутствие бобра на эмблеме CLIII “Aere quandoque salutem redimendam” («Иногда спасение приобретается деньгами») восходит к античной басне о его самооскоплении ради спасения от охотников (Aesop. Fab. 118). Грызун олицетворяет человека, вынужденного пожертвовать имуществом ради сохранения своей жизни.

Эмблема CLXVI “Aliquid mali propter vicinum malum” («Против того, кто погибнет от суровости своих же») иллюстрирует ХІ басню позднеримского поэта Авиана, который повествует о двух упавших в реку сосудах. Медный котел обещает глиняному горшку, что будет держаться в бурном потоке подальше от него, однако тот все равно опасается своего соседа, так как сравнительно хрупок. В более ранней версии этого же рассказа, принадлежащей Эзопу, акцент делается на том, что небезопасно бедному человеку жить рядом с сильным и жадным (Aesop. Fab. 346). По всей видимости, Альчиато не вставляет это объяснение, так как уверен, что его современники прекрасно знают приведенную историю. Недаром нравоучительная притча о двух сосудах включена также во второканоническую «Книгу премудрости Иисуса, сына Сирахова» ${ }^{10}$.

Басня «Лиса и маска» отражена в гравюре CLXXXIX “Mentem, non formam, plus pollere” («Разум, а не внешность, имеет значение»). Лиса увидела изящно

10 "Quid communicabit caccabus ad ollam? Quando enim se colliserint, confringetur" (Liber Ecclesiasticus 13.3) / «Какое общение у горшка с котлом? Этот толкнет его, и он разобьется» (Пер. с официального сайта РПЦ. URL: http://www.patriarchia.ru/bible/sir/13/, свободный). 


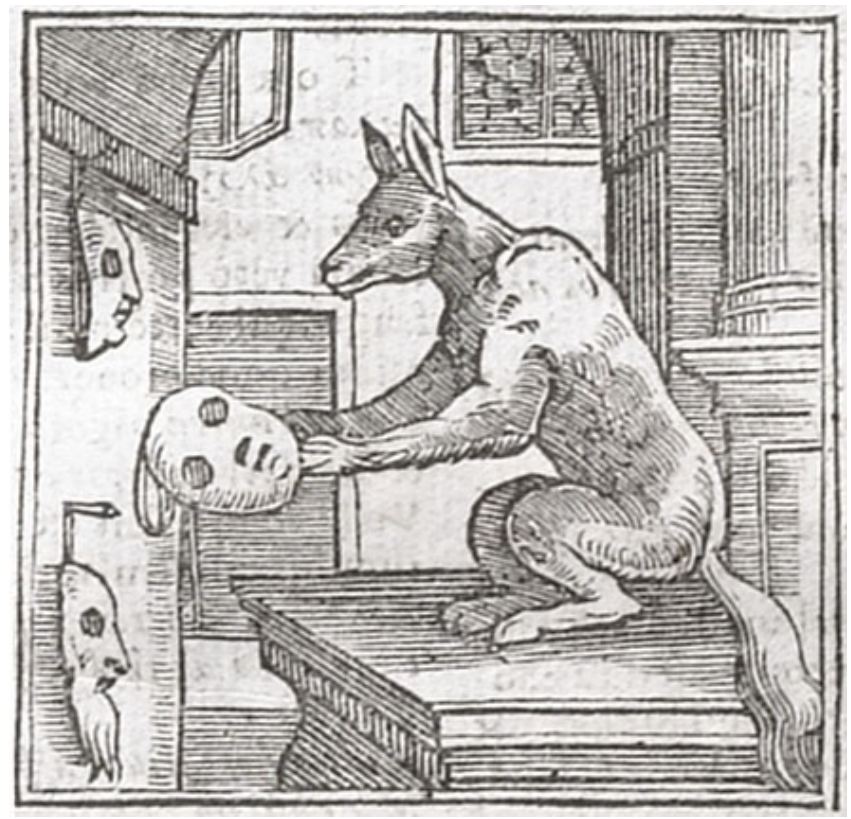

Рис. 9. Лиса и маска. Emblema CLXXXIX. Mentem, non formam, plus pollere (Разум, а не внешность, имеет значение)

выделанную человеческую голову и сказала: «Ну какова же голова! Мозга, однако, не имеет». У Эзопа животное забирается в мастерскую лепщика (Aesop. Fab. 27). Согласно Федру, маска была найдена на дороге (Phaedr. Fab. I. 7). Альчиато перемещает сцену на склад театрального реквизита и призывает больше ценить душу, а не внешность (рис. 9) ${ }^{11}$.

Мы обратили внимание, в общей сложности, на 155 символических композиций (73\% от общего числа). Они указывают на безусловную связь эмблематической интенции Андреа Альчиато с литературным наследием классической древности $^{12}$. Книга итальянского гуманиста изначально была посвящена другому видному юристу и коллекционеру, Конраду Пейтингеру, и, учитывая насыщенность античными аллюзиями, предназначалась для эрудированной публики. Теоретическая мысль последующих эмблематистов (Гийом де Ла Перьер, Иоанн Самбук, Чезаре Рипа и др.) также не в малой степени питалась от греко-римских истоков. Но первым на данном жанровом поприще был именно Альциат.

\section{Источники}

Aesop. Fab. - Басни Эзопа / Пер., статья и коммент. М.Л. Гаспарова. - М.: Наука, 1968. $320 \mathrm{c}$.

Alciati 1531 - Alciati A. Viri clarissimi d. Andreae Alciati iurisconsultiss. Mediola ad d. Chonradum Peutingerum Augustanum, iurisconsultum emblematum liber. - Augustae Vindelicorum: per Heynricum Steynerum, 1531. -86 p.

\footnotetext{
11 Эпиграмма начинается следующим образом: “Ingressa vulpes in Choragi pergulam” («Лиса попала в комнату хорега»). Под хорегом имеется в виду театральный постановщик.

12 «Многие собственные проблемы схоластической семиотики уходят корнями в тысячелетнюю толщу античной и средневековой традиции и вне этой традиции, опоры на нее или полемики с нею не могут быть поняты» [15, с. 18].
} 
Alciati 1621 - Alciati A. Emblemata cum commentarijs Claudij Minois i.c. Francisci Sanctij Brocensis, \& notis Laurentij Pignorij Patauini. - Patauij: Apud Petrum Paulum Tozzium, 1621. - 1003 p.

Ath. - Афиней. Пир мудрецов: в 2 т. / Пер. Н.Т. Голинкевич. - М.: Наука. - Т. 1, кн. 1-8. 2003. - 655 с.; Т. 2, кн. 9-15. - 2010. - 597 с.

Aur. Vict. Epit. - Секст Аврелий Виктор. Извлечения о жизни и нравах римских императоров / Пер. В.С. Соколова // Римские историки IV века. - М.: Росспэн, 1997. C. 124-162.

Cardano 2012 - Джсиоламо Кардано. О моей жизни / Ред.-сост. Ю.П. Зарецкий. - М.: Изд. дом Высш. шк. экономики, 2012. - 335 с.

Epigrammata Graeca 1993 - Греческая эпиграмма / Изд. подгот. Н.А. Чистякова. - СПб.: Наука, 1993. - 448 c.

Gell. N.A. - Авл Геллий. Аттические ночи: в 2 т. / Под общ. ред. А.Я. Тыжова, А.П. Бехтер. - СПб.: Гуманит. акад. - Т. 1, кн. I - X. - 2007. - 480 с.; Т. 2, кн. XI - XX. 2008. $-448 \mathrm{c}$.

Hdt. - Геродот. История: в 9 кн. / Пер. и прим. Г.А. Стратановского. - М.: Ладомир, ACT, 1999. - $752 \mathrm{c}$.

Liber Ecclesiasticus - Liber Iesu filii Sirach, seu Ecclesiasticus // Biblia Sacra iuxta Vulgatam versionem / Ed. R. Gryson. - Nördlingen: C.H. Beck, 2008. - S. 1029-1095.

Mart. Epigr. - Марк Валерий Марииал. Эпиграммы / Пер. Ф.А. Петровского; вступ.-ст. В.С. Дурова. - СПб.: Комплект, 1994. - 448 с.

Nep. Thrasyb. - Корнелий Неnот. [Фрасибул] // Корнелий Непот. О знаменитых иноземных полководцах. Из книги о римских историках / Пер. Н.Н. Трухиной. - М.: Изд-во МГУ, 1992. - С. 37-39.

Ovid. Met. - Публий Овидий Назон. Метаморфозы / Пер. С. В. Шервинского // Овидий. Собр. соч.: в 2 т. - М.: Студиа Биографика, 1994. - Т. 2. - С. 7-344.

Pal. Ant. - The Greek Anthology: 5 v. / With an English transl. by W.R. Paton. - London: William Heinemann Ltd.; New York: G.P. Putnam's sons. - V. 3, b. 9. - 1917. - 456 p.

Paus. - Павсаний. Описание Эллады: в 2 т. / Пер. С.П. Кондратьева. - М.: Ладомир, 1994. - Т. 1, кн. 1-4. - XXII, 364 c.

Phaedr. Fab. - Федр. Басни / Пер. М.Л. Гаспарова // Античная басня. - М.: Худож. лит., 1991. - C. 269-346.

Plin. N.H. - Pliny. Natural History: 10 v. / With an english transl. by H. Rackham, W.H.S. Jones, D.E. Eichholz. - Cambridge, Mass.: Harvard Univ. Press; London: William Heinemann Ltd. - V. 3, b. VIII - XI. - 1940. - 616 p.; V. 6, b. XXII - XXIII. - 1951. - 532 p.; V. 9, b. XXXIII - XXXV. - 1952. -421 p.

Plut. Ant. - Плутарх. [Антоний] // Плутарх. Сравнительные жизнеописания: в 2 т. / Изд. подгот. С.С. Аверинцев, М.Л. Гаспаров, С.П. Маркиш. - М.: Наука, 1994. - Т. 2. C. $398-443$.

Plut. Brut. - Плутарх. [Брут] // Плутарх. Сравнительные жизнеописания: в 2 т. / Изд. подгот. С.С. Аверинцев, М.Л. Гаспаров, С.П. Маркиш. - М.: Наука, 1994. - Т. 2.C. 474-503.

Plut. Mor. - Plutarch. Moralia: 15 v. / With an english transl. by F.C. Babbitt, W.C. Helmbold, Ph. H. de Lacy, B. Einarson et al. - Cambridge, Mass.: Harvard Univ. Press; London: William Heinemann Ltd. - V. 3. - 1931. - 600 p.; V. 6. - 1939. - 528 p.

Plut. Sol. - Плутарх. [Солон] // Плутарх. Сравнительные жизнеописания: в 2 т. / Изд. подгот. С.С. Аверинцев, М.Л. Гаспаров, С.П. Маркиш. - М.: Наука, 1994. - Т. 1. C. 92-114.

Polyaenus. Strat. - Полиэн. Стратегемы / Под общ. ред. А. К. Нефёдкина. - СПб.: Евразия, 2002. $-608 \mathrm{c.}$

Ps.-Appolod. Bibl. - Аполлодор. Мифологическая библиотека / Пер. В.Г. Боруховича. М.: АСТ, Астрель, 2004. - 350 с. 


\section{Литература}

1. Эмблематика и эмблематичность в западноевропейской и русской культуре. / Под ред. А.Е. Махова. - М.: Intrada, 2016. - 240 c.

2. Green H. Andrea Alciati and His Books of Emblems: A Biographical and Bibliographical Study. - London: Trübner \& Co, 1872. - 344 p.

3. Phillipson C. Andrea Alciati and his predecessors // J. Soc. Comp. Legis. - 1913. - V. 13, No 2. - P. 245-264.

4. Andrea Alciato and the Emblem Tradition: Essays in Honor of Virginia Woods Callahan / Ed. by P.M. Daly. - N. Y.: AMS Press, 1989. - 294 p.

5. Heckscher W.S. The Princeton Alciati Companion: A Glossary of Neo-Latin Words and Phrases Used by Andrea Alciati and the Emblem Book Writers of His Time, Including a Bibliography of Secondary Sources Relevant to the Study of Alciati's Emblems. N. Y.: Garland, 1989. - 296 p.

6. Klecker E. Des signes muets aux emblèmes chanteurs: les "Emblemata" d'Alciat et l'emblématique // Littérature. - 2007. - No 145. - P. 23-52. - doi: 10.3917/litt.145.0023.

7. Miedema H. The term emblema in Alciati // J. Warburg Courtauld Inst. - 1968. - V. 31. P. 234-250. - doi: 10.2307/750643.

8. Махов А.Е. Эмблематика. Макрокосм. - М.: Intrada, 2014. - 601 с.

9. Drysdall D.L. Préhistoire de l'emblème: Commentaires et emplois du terme avant Alciat // Nouvelle Revue du XVIe Siècle. - 1988. - F. 6. - P. 29-44.

10. Callahan V.W. Andrea Alciati // Contemporaries of Erasmus: A Biographical Register of the Renaissance and Reformation: 3 v. / Ed. by P.G. Bietenholz, T.B. Deutscher. - Toronto: Univ. of Toronto Press, 2003. - V. 1: A-E. - P. 23-26.

11. Bregman A. Emblemata: The Emblem Books of Andrea Alciato: A Leaf Book. -Newtown: Bird \& Bull Press, 2007. - 139 p.

12. Панофский Э. Этюды по иконологии: Гуманистические темы в искусстве Возрождения. - СПб.: Азбука-классика, 2009. - 432 с.

13. Czarski B. Respublica Liberata. The coin of Brutus commemorating the ides of march in the emblematic interpretation of Alciatus // Wiadomości Numizmatyczne. - 2015. R. 59. - P. 249-284.

14. Зеленин Д.А. “Quid sit emblema?”: эволюция семантики эмблемы от античности до Андреа Альчиато // Новый филол. вестн. - 2015. - № 3 - С. 30-43.

15. Вдовина Г.В. Язык неочевидного. Учения о знаках в схоластике XVII в. - М.: Ин-т философии, теологии и истории св. Фомы, 2009. - 648 с.

Поступила в редакцию 06.06.2019

\footnotetext{
Данилов Евгений Сергеевич, кандидат исторических наук, доцент кафедры всеобщей истории Ярославский государственный университет им. П.Г. Демидова ул. Советская, д. 14, г. Ярославль, 150003, Россия

E-mail:e.danilov@uniyar.ac.ru
} 
UCHENYE ZAPISKI KAZANSKOGO UNIVERSITETA. SERIYA GUMANITARNYE NAUKI

(Proceedings of Kazan University. Humanities Series)

2020, vol. 162, no. 1, pp. 177-190

doi: $10.26907 / 2541-7738.2020 .1 .177-190$

\title{
Antiquitized Emblems of Andrea Alciato
}

\author{
E.S. Danilov \\ P.G. Demidov Yaroslavl State University, Yaroslavl, 150003 Russia \\ E-mail: e.danilov@uniyar.ac.ru
}

Received June 6, 2019

\begin{abstract}
Emblems are visible metaphors, a synthesis of words and images. They traditionally embodied simple earthly truths, moral standards, and political principles. Emblem studies is a special historical discipline studying symbolic representations of certain notions or ideas. Scholars distinguish several sources of this discipline: Egyptian hieroglyphics; epigrammatic, fabular, and numismatic heritage of the Classical Antiquity; medieval fabliau and proverbs; bestiary images of both epochs.

In this paper, the "Emblemata" created by Andrea Alciato (1492-1550), a Late Renaissance writer and erudite, was analyzed. Particular attention was drawn to certain groups of mythological characters and historical personalities of the classical antiquity. The prevailing appeal to mythological creatures was noticed. The main works of Greek and Roman authors, which became sources for A. Alciato, were revealed. In particular, the "Palatine Anthology", the fables of Aesop and Avian were an important source of inspiration for A. Alciato. The analysis is based on 155 symbolic compositions $(73 \%$ of the total number) and indicates a close connection of A. Alciato's emblematic intention with the literary heritage of the classical antiquity. The book of the Italian humanist was originally intended for the erudite public. The theoretical ideas of subsequent emblematists were also based on Greco-Roman sources. A. Alciato was the first in this genre.
\end{abstract}

Keywords: emblem, Alciato, ancient culture

\section{Figure Captions}

Fig. 1. Andrea Alciato. Engraved image from the book of 1589. Source - Cornell University Library's website. Available at: https://digital.library.cornell.edu/catalog/ss:574286.

Fig. 2. The lame Litae, the goddesses of prayers, slowly follow the fast-winged Atë, the goddess of delusion and folly, correcting her mistakes. Emblema CXXXI. Remedia in arduo, mala in prono esse (Remedies are in the steep upward path, and woes in the downward direction). Hereinafter pictures taken from A. Alciato's works published in 1621. - University of Glasgow Library. Available at: https://www.emblems.arts.gla.ac.uk/alciato/contents.php?id=A21a.

Fig. 3. Thrasybulus rewarded by a wreath of olive. Emblema CXXXV. Optimus civis (The best citizen).

Fig. 4. Mark Antony. Emblema XXIX. Etiam ferocissimos domari (Even the fiercest are overcome).

Fig. 5. Marcus Junius Brutus' coin. Emblema CLI. Respublica liberata (The republic restored to freedom).

Fig. 6. A Hun near the Black Sea. Emblema XXXVII. Omnia mea mecum porto (All that is mine I carry with me).

Fig. 7. Sophocles and Archippa. Emblema CXVII. Senex puellam amans (An old man in love with a girl).

Fig. 8. Oak tree is a symbol of power. Emblema XLII. Firmissima convelli non posse (What stands firmest cannot be overthrown).

Fig. 9. A fox and a mask. Emblema CLXXXIX. Mentem, non formam, plus pollere (Mind, not outward form, prevails). 


\section{References}

1. Emblematika i emblematichnost'v zapadnovropeiskoi i russkoi kul'ture [Emblem Studies and Emblems in the Western European and Russian Cultures]. Makhov A.E. (Ed.). Moscow, Intrada, 2016. 240 p. (In Russian)

2. Green H. Andrea Alciati and His Books of Emblems: A Biographical and Bibliographical Study. London, Trübner \& Co, 1872. 344 p.

3. Phillipson C. Andrea Alciati and his predecessors. Journal of the Society of Comparative Legislation, 1913, vol. 13, no. 2, pp. 245-264.

4. Andrea Alciato and the Emblem Tradition: Essays in Honor of Virginia Woods Callahan. Daly P.M. (Ed.). New York, AMS Press, 1989. 294 p.

5. Heckscher W.S. The Princeton Alciati Companion: A Glossary of Neo-Latin Words and Phrases Used by Andrea Alciati and the Emblem Book Writers of His Time, Including a Bibliography of Secondary Sources Relevant to the Study of Alciati's Emblems. New York, Garland, 1989. 296 p.

6. Klecker E. Des signes muets aux emblèmes chanteurs: les "Emblemata" d'Alciat et l'emblématique. Littérature, 2007, no. 145, pp. 23-52. doi: 10.3917/litt.145.0023.

7. Miedema H. The term emblema in Alciati. Journal of the Warburg and Courtauld Institutes, 1968, vol. 31, pp. 234-250. doi: 10.2307/750643.

8. Makhov A.E. Emblematika. Makrokosm [Emblem Studies. Macrocosm]. Moscow, Intrada, 2014 601 p. (In Russian)

9. Drysdall D.L. Préhistoire de l'emblème: Commentaires et emplois du terme avant Alciat. Nouvelle Revue du XVIe Siècle, 1988, f. 6, pp. 29-44. (In French)

10. Callahan V.W. Andrea Alciati. In: Contemporaries of Erasmus: A Biographical Register of the Renaissance and Reformation. Bietenholz P.G., Deutscher T.B. (Eds.). Vol. 1: A-E. Toronto, Univ. of Toronto Press, 2003, pp. 23-26.

11. Bregman A. Emblemata: The Emblem Books of Andrea Alciato: A Leaf Book. Newtown, Bird \& Bull Press, 2007. 139 p.

12. Panofskii E. Etyudy po ikonologii: Gumanisticheskie temy v iskusstve Vozrozhdeniya [Etudes in Iconology: Humanistic Themes in Renaissance Art]. St. Petersburg, Azbuka-Klassika, 2009. 432 p. (In Russian)

13. Czarski B. Respublica Liberata. The coin of Brutus commemorating the ides of march in the emblematic interpretation of Alciatus. Wiadomości Numizmatyczne, 2015, r. 59, pp. 249-284.

14. Zelenin D.A. "Quid sit emblema?": Evolution of the emblem semantics from Antiquity to Andrea Alciato. Novyi Filologicheskii Vestnik, 2015, no. 3, pp. 30-43. (In Russian)

15. Vdovina G.V. Yazyk neochevidnogo. Ucheniya o znakakh v skholastike XVII v. [The Language of the Subtle. The Doctrines of Signs in Scholasticism of the 16th Century]. Moscow, Inst. Filos., Teol., Ist. Sv. Fomy, 2009. 648 p. (In Russian)

Для цитирования: Данилов Е.С. Антикизированные эмблемы Альциата // Учен. зап. Казан. ун-та. Сер. Гуманит. науки. - 2020. - Т. 162, кн. 1. - С. 177-190. - doi: 10.26907/25417738.2020.1.177-190

For citation: Danilov E.S. Antiquitized emblems of Andrea Alciato. Uchenye Zapiski Kazanskogo Universiteta. Seriya Gumanitarnye Nauki, 2020, vol. 162, no. 1, pp. 177-190. doi 10.26907/2541-7738.2020.1.177-190. (In Russian) 